\title{
Population biology of Trichomycterus sp. (Siluriformes, Trichomycteridae) in Passa Cinco stream, Corumbataí River sub-basin, São Paulo State, southeastern Brazil
}

\author{
Rondineli, GR.*, Carmassi, AL. and Braga, FMS. \\ Departamento de Zoologia, Instituto de Biociências, Universidade Estadual Paulista - UNESP, \\ Av. 24a, 1515, Bela Vista, CP 199, CEP 13506-900, Rio Claro, SP, Brazil \\ *e-mail: giulianna.rondineli@gmail.com \\ Received January 22, 2008 - Accepted April 14, 2008 - Distributed August 31, 2009
}

(With 7 figures)

\begin{abstract}
The aim of this work was to characterise the population of Trichomycterus sp. in Passa Cinco stream, regarding length structure, sex ratio, diet and reproductive aspects, in accordance with drought and rainy season periods and longitudinal gradient, as well as to analyse its corporal condition in a temporal dimension. Six samplings were accomplished with the use of electric fishing equipment in three different sites in Passa Cinco stream, contemplating sites of order two, three and four, during the months of May, July, September and November of 2005; and January and March of 2006. Three hundred and forty one individuals were captured, composed of 203 males, 99 females and 39 immatures. The smallest captured individual, an immature, presented $28 \mathrm{~mm}$ of standard length and the largest, a male, $85 \mathrm{~mm}$. There was not significant variation in repletion degree and accumulated fat in the visceral cavity of the individuals analysed during the considered periods. Eleven different food items were found in the stomach contents. Considering the whole sampling period, immature Diptera was a preferential item and other items were found as occasionally ingested. Spearman and Friedman tests did not find significant differences in the diet of Trichomycterus sp. in the periods and sampling sites, respectively. The average of absolute fecundity was of 73 oocytes, and the parceled type of spawning was performed. Both males and females of Trichomycterus sp. presented significant differences in their corporal conditions in the considered periods, and in the rainy season, these fishes were in better condition.
\end{abstract}

Keywords: diet, reproduction, fecundity, corporal condition.

\section{Biologia populacional de Trichomycterus sp. (Siluriformes, Trichomycteridae) no Rio Passa Cinco, sub-bacia do Rio Corumbataí, estado de São Paulo, sudeste do Brasil}

\section{Resumo}

O objetivo deste trabalho foi caracterizar a população de Trichomycterus sp. do rio Passa Cinco com relação à estrutura em comprimento, proporção sexual, dieta e aspectos reprodutivos de acordo com os períodos de seca e cheia e gradiente longitudinal, bem como analisar sua condição corporal na dimensão temporal. Seis amostragens, fazendo uso do equipamento de pesca elétrica, foram realizadas em três pontos distintos do Rio Passa Cinco, contemplando trechos de ordem dois, três e quatro nos meses de maio, julho, setembro e novembro de 2005 e janeiro e março de 2006. Foram capturados 341 indivíduos, sendo: 203 machos, 99 fêmeas e 39 imaturos. O menor indivíduo capturado, um exemplar imaturo, apresentou $28 \mathrm{~mm}$ de comprimento padrão e o maior, um macho, $85 \mathrm{~mm}$. Não houve variação significativa nos graus de repleção e de gordura acumulada na cavidade visceral dos exemplares analisados entre os períodos considerados. Onze diferentes itens alimentares foram encontrados nos conteúdos estomacais. Considerando todo o período de amostragem, larvas de Diptera foram um item preferencial e os demais itens ingeridos, ocasionais. Os testes de Spearman e Friedman não encontraram diferenças significativas na dieta de Trichomycterus sp. entre períodos e pontos amostrais, respectivamente. A fecundidade absoluta média foi de 73 ovócitos, sendo a desova do tipo parcelada. Tanto os machos quanto as fêmeas de Trichomycterus sp. apresentaram diferenças significativas em suas condições corporais nos períodos considerados e, no período de cheia, os peixes apresentaram melhores condições.

Palavras-chave: dieta, reprodução, fecundidade, condição corporal. 


\section{Introduction}

Trichomycteridae catfish comprise approximately 226 species (de Pinna and Wosiacki, 2003) of smallsized fishes (de Pinna, 1998) which in general, inhabit small water courses with rocky river beds, strong currents and clear waters (Arratia, 1983; de Pinna 1998), which results in a high degree of endemism within the family (Costa, 1992; de Pinna, 1992; Bizerril, 1994).

Species of the Trichomycterus Valenciennes in Humboldt, 1832 genus are widely distributed in the neotropical area (de Pinna 1998; Román-Valencia, 2001) and, in agreement with Wosiacki (2005), a real estimate of species diversity of this genus is far from being completed, because many species have been recently described, for example: T. catamarcensis (Fernández and Vari, 2000), T. yuska (Fernández and Schaefer, 2003), T. maracaya (Bockmann and Sazima, 2004), T. trefauti (Wosiacki, 2004), T. guaraquessaba (Wosiacki, 2005), T. tupinamba and T. jacupiranga (Wosiacki and Oyakawa, 2005).

Although a substantial amount of work exists on stream fishes, there are still few studies that deal with the biology of the species, concerning the feeding, reproduction or dynamics of those populations (Braga, 2006), considering that often those environments are possessors of endemic ichthyofaunas. Castro (1999) emphasises the need for studies in freshwater systems of small-sized fishes which involve systematisation, evolution and biology.

Works that deal with the biology and ecology of Trichomycterus species are still few. Some aspects of diet and/or reproduction are known for $T$. aerolatus (Manriquez et al., 1988; Huaquín et al., 2002; Habit et al., 2005 and Scott et al., 2007), T. caliensi (RománValencia, 2001), T. chaberti (Pouilly and Miranda, 2003), T. chiltoni (Scott et al., 2007), T. corduvense (Marraro et al., 2005), T. itacarambiensis (Trajano, 1997) and two other species are still not resolved taxonomically (Casatti, 2003 and Chará et al., 2006).

Most tropical waters show seasonal variations mainly caused by hydrometric oscillations (Lowe-McConnell, 1999) that affect and modify the habitat (Aranha et al., 2000). On account of that, fishes of Neotropical streams face, during their life cycle, temporary and space variations that can be reflected in diet, reproduction and corporal condition.

Observing that there is a relative shortage of information about species of that genus, the present work was proposed with the objective of characterising the population of Trichomycterus sp. in Passa Cinco stream regarding length structure, sex ratio, diet and reproductive aspects in accordance with drought and rainy season periods and longitudinal gradient, as well as to analyse its corporal condition in a temporal dimension, in such a way as to contribute to the understanding of biological aspects of that important component of the Neotropical ichthyofauna.

\section{Material and Methods}

This work was accomplished in Passa Cinco stream, which is one of the main rivers of the Corumbataí River sub-basin. It presents $525 \mathrm{~km}^{2}$ of drainage area and its course covers about $60 \mathrm{~km}$, from its headwater in serra da Cachoeira, a component of the complex of serra de Itaqueri, located in the local authority of Itirapina, with an altitude of 1,000 m; until its mouth in the Corumbataí river, with an altitude of $480 \mathrm{~m}$. Nowadays, $51.72 \%$ of its surface is occupied by planted pasture area, $14.13 \%$ by sugarcane plantations, $15.67 \%$ by native forest and $0.74 \%$ by scrubland (Valente, 2001).

Six samplings were accomplished in three different sites (with the following geografical coordinates: site 1 $22^{\circ} 23^{\prime} 36^{\prime \prime} \mathrm{S}$ and $47^{\circ} 53^{\prime} 08^{\prime \prime} \mathrm{W}$, site $2-22^{\circ} 22^{\prime} 10^{\prime \prime} \mathrm{S}$ $47^{\circ} 51^{\prime} 22^{\prime \prime} \mathrm{W}$, site $3-22^{\circ} 21^{\prime}$ ' $63^{\prime \prime} \mathrm{S}$ and $47^{\circ} 48^{\prime} 48^{\prime \prime} \mathrm{W}$ ) in the region of the high course of Passa Cinco stream (Figure 1), in May, July, September and November of 2005 and January and March of 2006.

The rainfall and air temperature data during the sampling period were obtained at CEAPLA (Centre of Analysis and Environmental Planning), of the Universidade Estadual Paulista, in Rio Claro.

Electric fishing equipment was used in each site, connected to a generator with maximum capacity of $1,500 \mathrm{~V}$ and $60 \mathrm{~Hz}$. In these places passages of $50 \mathrm{~m}$

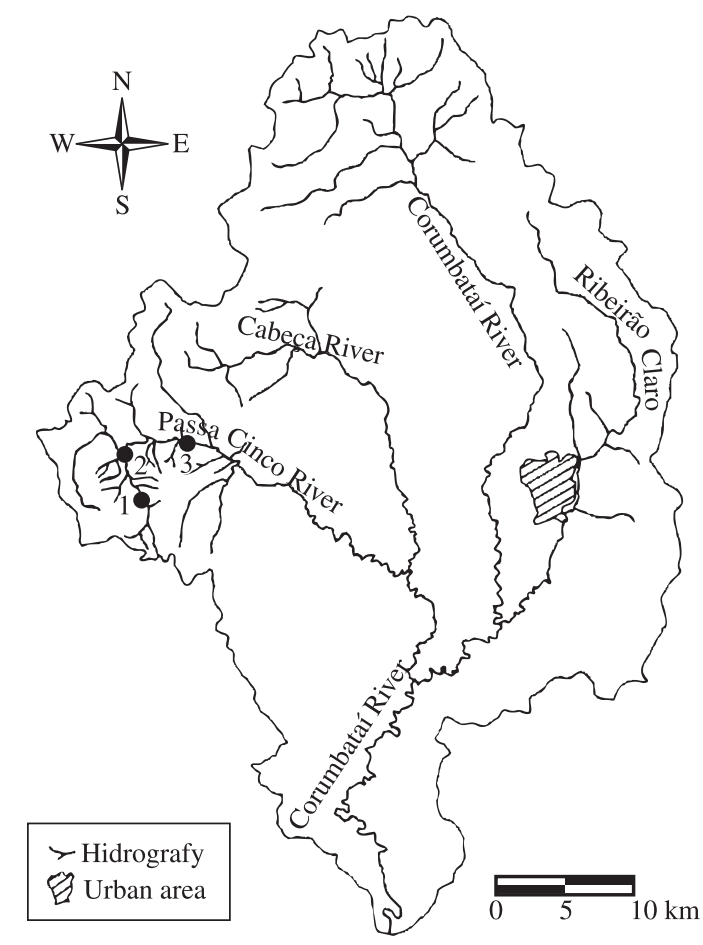

Figure 1. Hydrographic map of the Corumbataí River subbasin, showing the sampled sites (modified from Garcia et al., 2004). 1) Sample site 1; 2) Sample site 2; and 3) Sample site 3 . 
were determined, where the equipment was placed just once, without a contention net.

After each sampling, the fishes were put into plastic bags, and then fastened in formalina $10 \%$ for 2 days and later transferred to alcohol $70 \%$ until the accomplishment of the analysis.

In the laboratory, the species of Trichomycterus sp. were selected from other species and the following data were taken: total and standard length in centimetres, total weight in grams, repletion degree of the stomach (GR), degree of fat accumulated in the visceral cavity (GA), sex and state of gonadal maturation (Braga, 1990). Voucher specimens were deposited in the icththyological collection of the ichthyology laboratory of the Universidade Estadual Paulista, in Rio Claro.

To evaluate the degree of stomach repletion (filling state of the stomach), the following values were attributed: 1 for stomachs considered empty, 2 for stomachs partially full and 3 for stomachs completely full (Braga, 1990). The stomachs with repletion degree equivalent to 3 were extracted from the visceral cavity for a subsequent study of species diet.

For the degree of fat accumulated in the visceral cavity, three categories were attributed: 1 for the visceral cavity that did not present fat, 2 for the visceral cavity partially filled with fat and 3 for the visceral cavity full of fat (Braga, 1990).

In agreement with a previously established scale (Vazzoler, 1996), four different gonadal maturation stages were considered: A, immature; $\mathrm{B}$, in maturation or resting; C, mature; and D, spent. For the study of fecundity, in accordance with Vazzoler (1996), ovaries in stage $\mathrm{C}$ were extracted from the visceral cavity and weighed; their membranes were then sectioned longitudinally throughout and immersed in Gilson solution.

The structure of the Trichomycterus sp. population was analysed regarding the proportion among sexes (Vazzoler, 1996) and the distribution in length classes (Gomiero and Braga, 2005).

To verify if the proportion between males and females of this species was different from the expected (1:1), the test of $\chi^{2}$ (Siegel, 1975) was used, considering $\alpha=0.05$.

The length structure (distribution in length classes) for each sex was determined and the KolmogorovSmirnov test (Sokal and Rohlf, 1995) was used in two samples to verify whether the length distributions among the sexes presented differences, $\alpha=0.05$.

In order to test the hypothesis in which repletion and accumulated fat degrees in the visceral cavity depend on the period of the year, a contingency table was made, and the values were tested using the $\chi^{2}$ test to verify the hypothesis of independence of the two variables categorised (Vieira, 2004), $\alpha=0.05$.

The GPA method (Braga, 1999) was applied to stomachs considered replete. This method consists of attributing values to food items found in certain species, according to the participation of each item in the analysed stomach. The value 4 is attributed when only one food item exists in the stomach; when there appears to be more than one item for the stomach, the adopted values are 3, 2 or 1 , according to its participation in the analysed stomach content. The value of GPA is obtained through the sum of the values attributed to each item, divided by the number of analysed stomachs. Thus, food items can be classified as absolute preferential $(\mathrm{GPA}=4)$, preferential in high degree $(3 \leq \mathrm{GPA}<4)$, preferential $(2 \leq \mathrm{GPA}<3)$, secondary $(1 \leq \mathrm{GPA}<2)$ and occasional $(0<\mathrm{GPA}<1)$.

The Spearman test (Siegel, 1975) was applied to the values of GPA to verify if there was a correlation between the items ingested by the species and the sampling time (drought and rainy season) and the Friedman test was used to verify if there existed any correlation between ingested items and sampling sites.

On account of the close relationship between the maturation progress of oocytes and the increase of volume, which implies an increase of the weight of the ovaries, the gonadossomatic relationship (RGS), that shows the percentage of gonads on individuals' total weight, is an efficient indicator of the ovaries functional state (Vazzoler, 1996). Also, temporary variation of RGS supplies information about the reproductive period of species or population. Therefore, inferences on the reproductive period of species were made through the frequency of individuals with gonads in different stages of maturity and the temporal variation in gonadossomatic relationship (RGS).

After the oocytes were released from the ovarian tissue, they were washed in successive baths in alcohol $70 \%$, cleaned of the ovarian epithelium and stored in alcohol to $70 \%$.

Dissociated oocytes were analysed by the volumetric method to estimate the absolute fecundity (Vazzoler, 1996). After ovary dissociation, yolky oocytes were measured at random under a stereomicroscope equipped with a micrometrical ocular $(1$ d.o.m. $=61.2 \mu \mathrm{m})$. Once the number of oocytes contained in the ovaries and the distribution of oocyte diameters were known, the absolute fecundity was considered for each female.

Through the distribution of diameter frequency of oocytes, the spawning type was verified by the presence of a single moda of yolky oocytes (total spawning) or more than a moda of yolky oocytes (parceled spawning), according to Vazzoler (1996).

To evaluate the corporal condition of species, a covariance analysis was applied (Cetra, 2005), whose model was:

$\mathrm{P}=\mathrm{Cte}+\mathrm{C}+\mathrm{E}+\mathrm{e}$

where $\mathrm{P}$ represents weight of individuals $(\mathrm{g})$, Cte is the constant of the model, $\mathrm{C}$ is standard length $(\mathrm{mm}), \mathrm{E}$ is time (drought or rainy season) and e is error. A fish will possess a better corporal condition than another when, for a given medium length, it presents a larger weight. To weight and length data, logarithmic transformation 
$(\ln +1)$ was applied and distribution of residues was verified through the Lilliefors test.

\section{Results}

\subsection{Environmental characterisation}

During the period of study, the lowest air temperatures were registered in July of $2005\left(18.8^{\circ} \mathrm{C}\right)$ and the highest in January of $2006\left(25.9^{\circ} \mathrm{C}\right)$. The total rainfall level varied from $3.6 \mathrm{~mm}$ in July of 2005 to $175.5 \mathrm{~mm}$ in December of 2005. In Figure 2, the monthly medium values of air temperature and medium values of rainfall are presented. Based on these values, it was identified that the first three samples belonged to the drought season (autumn/winter) and the last three samples belonged to the rainy season (spring/summer).

\subsection{Population structure}

During the collecting period, 341 individuals were collected, consisting of 203 males, 99 females and $39 \mathrm{im}$ matures. The proportion between males and females was significantly different from that expected $\left(\chi^{2}=35.81\right.$; $\mathrm{p}<0.001$ ), in a proportion of 2.05 males for each female.

The length structure of these individuals is represented in Figure 3. The smallest captured individual,

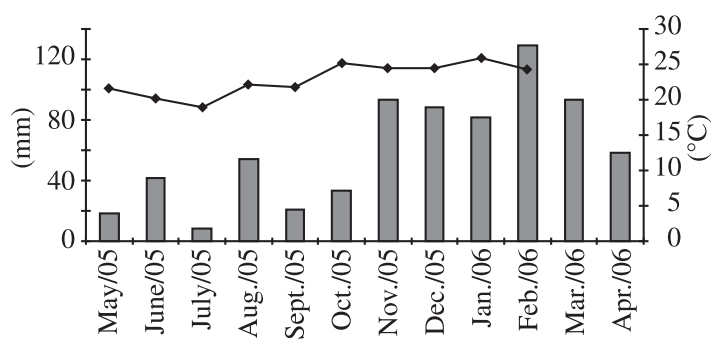

$$
\square \text { Rainfall level (mm) }
$$$$
\rightarrow \text { Temperature }\left({ }^{\circ} \mathrm{C}\right)
$$

Figure 2. Distribution of monthly medium values of air temperature and monthly medium values of rainfall level in the sampling period (May of 2005 to April of 2006). an immature specimen, presented $28 \mathrm{~mm}$ of standard length and the largest, a male, $85 \mathrm{~mm}$. The results of the Kolmogorov-Smirnov test indicate significant differences $\left(\chi^{2}=0.242 ; p=0.001\right)$ between the lengths of males and females.

\subsection{Variation in repletion degrees and accumulated fat in visceral cavity}

The frequencies of different repletion degrees and accumulated fat in the visceral cavity during drought and rainy season times are presented in Figure 4. There was not significant variation $(\mathrm{p}>0.05)$ in repletion degrees $\left(\chi^{2}=5.191 ; \mathrm{gl}=2 ; \mathrm{p}=0.075\right)$ and in accumulated fat of the visceral cavity $\left(\chi^{2}=0.79 ; \mathrm{gl}=2 ; \mathrm{p}=0.67\right)$ in the analysed specimens during the considered periods.

\subsection{Diet}

Of 341 Trichomycterus sp. specimens captured, 60 full stomachs were analysed. Eleven different food items were found in the stomach contents: immature Diptera (Chironomidae larvae, Simulidae larvae and Caoboridae larvae), immature Trichoptera, immature insects (mainly Coleoptera larvae), immature Plecoptera, immature Ephemeroptera, terrestrial insects (Coleoptera, Hymenoptera, Diptera, Homoptera), remains of insects (paws, wings, antennae), Arachnida (spiders and aquatic acarids), algae, worms (Nematoda) and detritus.

Considering the whole sampling period, the item immature Diptera was considered preferential and the other items ingested occasionally (Table 1).

When drought and rainy season periods were compared, the item immature Diptera remained preferential during the drought time and the other ingested items were considered occasional; at that time of rainy season, the item immature Diptera started to be a secondary item, the same as immature insect item, and the other items were occasionally ingested (Table 2).

Spearman's test showed that there was a correlation between diets of Trichomycterus sp. in both drought and rainy season periods $(\mathrm{r}=0.627 ; \mathrm{p}<0.05)$, revealing similar diets.

The values of GPA for food items consumed in each one of the sample sites are met in Table 3. Trichomycterus sp. had the item immature Diptera with

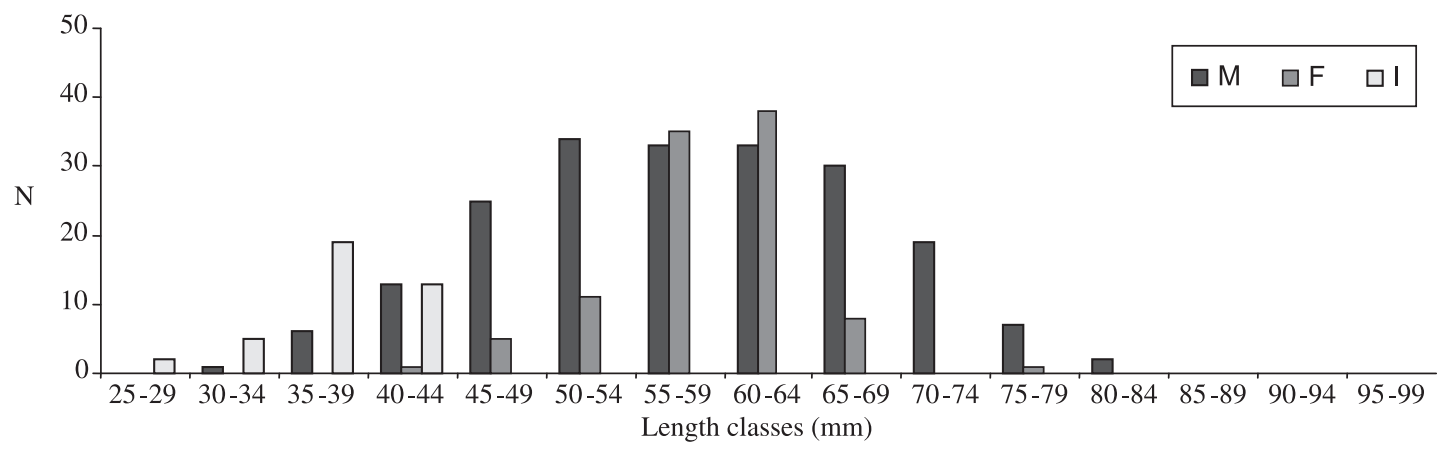

Figure 3. Numeric distribution of males, females and immatures of Trichomycterus sp. according to class of standard length $(\mathrm{mm})$. 
the largest levels of GPA at the three considered sites. Immature insects were also an important item at sites 2 and 3 , and they were considered a secondary item in the diet. A larger variety of food items was ingested by Trichomycterus sp. at site 1 , when compared with the two subsequent sites.

The Friedman test didn't find any significant difference in the diet of Trichomycterus sp., comparing the different sampling sites $\left(\chi^{2}=1.27 ; \mathrm{p}=0.058\right)$.

\subsection{Reproduction}

Of 341 analysed specimens, $12.6 \%$ presented gonads of an immature state (A), $68.6 \%$ in maturation or resting (B), $18.8 \%$ mature (C) and none were considered spent (D).

Table 1. Food items found in Trichomycterus sp stomachs, sum of values attributed to each item $\left(\mathrm{S}_{\mathrm{i}}\right)$, feeding preference degree of each item (GPA) with its respective classification.

\begin{tabular}{lrcc}
\hline \multicolumn{1}{c}{ Food items } & Si & GPA & Classification \\
\hline Immature Diptera & 131 & 2.18 & Preferential \\
Immature Plecoptera & 22 & 0.37 & Occasional \\
Immature Trichoptera & 8 & 0.13 & Occasional \\
Immature Ephemeroptera & 19 & 0.32 & Occasional \\
Immature insect & 57 & 0.96 & Occasional \\
Algae & 7 & 0.12 & Occasional \\
Insect remains & 19 & 0.32 & Occasional \\
Worms (Nematoda) & 1 & 0.02 & Occasional \\
Detritus & 3 & 0.05 & Occasional \\
Terrestrial insects & 4 & 0.07 & Occasional \\
Arachnida & 2 & 0.04 & Occasional \\
\hline
\end{tabular}
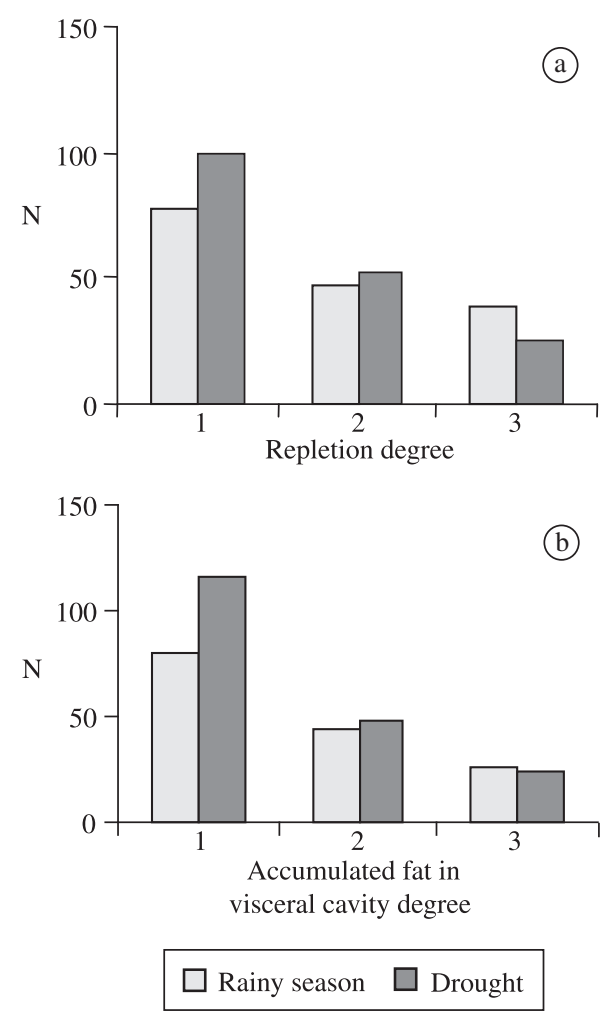

Figure 4. Numeric distribution of a) variations in repletion degree ( 1 for stomachs considered empty, 2 for stomachs partially full and 3 for stomachs completely full) and b) fat accumulated in visceral cavity ( 1 for the visceral cavity that doesn't present fat, 2 for the visceral cavity partially filled with fat and 3 for the visceral cavity full of fat) of Trichomycterus sp. between drought and rainy season periods.

Table 2. Values of feeding preference degree obtained by the different food items eaten by Trichomycetrus sp according to sampling period (drought and rainy season), sum of values attributed to each item ( $\mathrm{Si}$ ), feeding preference degree of each item (GPA) with its respective classification.

\begin{tabular}{|c|c|c|c|c|c|c|}
\hline \multirow[t]{2}{*}{ Food items } & \multicolumn{3}{|c|}{ Drought } & \multicolumn{3}{|c|}{ Rainy season } \\
\hline & $\mathbf{S i}$ & GPA & Classification & Si & GPA & Classification \\
\hline Immature Diptera & 74 & 2.39 & Preferential & 57 & 1.96 & Secondary \\
\hline Immature Plecoptera & 13 & 0.42 & Occasional & 9 & 0.31 & Occasional \\
\hline Immature Trichoptera & 6 & 0.19 & Occasional & 2 & 0.07 & Occasional \\
\hline Immature Ephemeroptera & 11 & 0.35 & Occasional & 8 & 0.28 & Occasional \\
\hline Immature insect & 25 & 0.81 & Occasional & 32 & 1.1 & Secondary \\
\hline Algae & 7 & 0.23 & Occasional & - & - & - \\
\hline Remains of insect & 3 & 0.1 & Occasional & 16 & 0.55 & Occasional \\
\hline Worms (Nematoda) & 1 & 0.03 & Occasional & - & - & - \\
\hline Detritus & - & - & - & 3 & 0.1 & Occasional \\
\hline Terrestrial insects & 2 & 0.06 & Occasional & 2 & 0.07 & Occasional \\
\hline Arachnida & - & - & Occasional & 2 & 0.07 & Occasional \\
\hline
\end{tabular}


Table 3. Values of feeding preference degree obtained by the different food items eaten by Trichomycetrus sp according to sampling sites $(1,2$, e 3$)$, sum of values attributed to each item $\left(\mathrm{S}_{\mathrm{i}}\right)$, feeding preference degree of each item (GPA) with its respective classification.

\begin{tabular}{|c|c|c|c|c|c|c|c|c|c|}
\hline \multirow[t]{2}{*}{ Food items } & \multicolumn{3}{|c|}{ Site 1} & \multicolumn{3}{|c|}{ Site 2} & \multicolumn{3}{|c|}{ Site 3} \\
\hline & $\mathbf{S i}$ & GPA & Classification & $\mathrm{Si}$ & GPA & Classification & $\mathrm{Si}$ & GPA & Classification \\
\hline Immature Diptera & 108 & 2.35 & Preferential & 14 & 2.8 & Preferential & 12 & 1.71 & Secondary \\
\hline Immature Plecoptera & 19 & 0.41 & Occasional & 2 & 0.4 & Occasional & - & - & - \\
\hline Immature Trichoptera & 4 & 0.09 & Occasional & 2 & 0.4 & Occasional & 2 & 0.29 & Occasional \\
\hline Immature Ephemeroptera & 11 & 0.24 & Occasional & 4 & 0.8 & Occasional & 4 & 0.57 & Occasional \\
\hline Immature insect & 41 & 0.89 & Occasional & 6 & 1.2 & Secondary & 10 & 1.43 & Secondary \\
\hline Algae & 11 & 0.24 & Occasional & - & - & - & 2 & 0.29 & Occasional \\
\hline Remains of insect & 1 & 0.02 & Occasional & - & - & - & - & - & - \\
\hline Worms (Nematoda) & 6 & 0.13 & Occasional & - & - & - & - & - & - \\
\hline Detritus & 3 & 0.06 & Occasional & - & - & - & - & - & - \\
\hline Terrestrial insects & 2 & 0.04 & Occasional & 2 & 0.4 & Occasional & - & - & - \\
\hline Arachnida & 2 & 0.04 & Occasional & - & - & - & - & - & - \\
\hline
\end{tabular}

Considering each sampling, the presence of mature individuals occurred from September, and the largest percentage happened in January (Figure 5). The gonadossomatic relationship presented growing values from September to January, with subsequent decline in March (Figure 6).

Thus, the reproductive period of Trichomycterus sp. happens from September (at the end of the drought period) to March (including the whole rainy season period). The largest percentage of individuals with mature gonads and higher value of gonadossomatic relationship found in January suggests the peak of reproductive period of Trichomycterus sp.

\subsection{Fecundity}

17 ovaries of Trichomycterus sp. were analysed. When the distributions of diameter frequency of yolky oocytes, according to the last moda position ( 36 d.o.m. = 2,203.2 $\mu \mathrm{m}$ ), were joined, from the group of less developed oocytes to the more developed, two groups were defined, suggesting a parceled spawning (Figure 7). It can be said that, from the diameter of 30 d.o.m. $(1,836 \mu \mathrm{m})$, the yolky oocytes are eliminated.

The absolute fecundity average was of 73 oocytes, with standard deviation of 26.

The absolute fecundities of female species didn't present a correlation with the respective lengths and total weights $(p>0.05)$. It was not possible to find the equation that would describe the population fecundity.

\subsection{Corporal condition}

The estimated values of intercept, angular coefficient and coefficient of correlation in length-weight relationships for males and females, in drought and rainy season periods, are presented in Table 4.

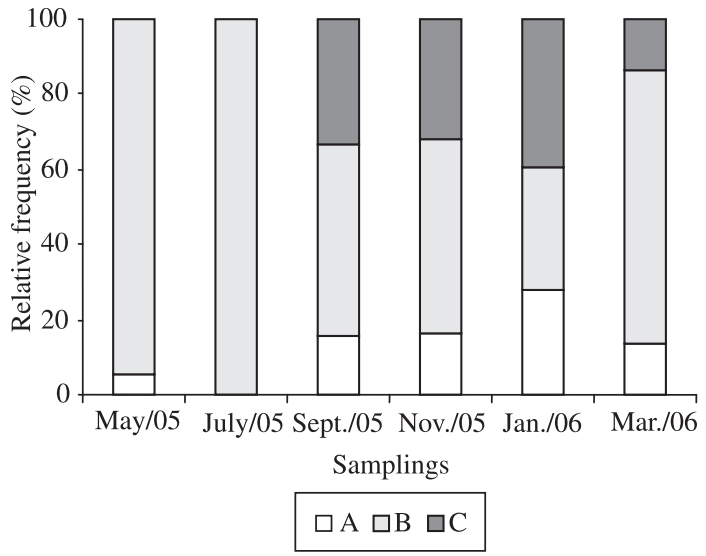

Figure 5. Relative frequency of Trichomycterus sp. individuals in different states of gonadal development in each sampling (A: immature individuals; B: individuals with gonads in development or rest; C: individuals with ripe gonads).

Length-weight relationships were different between males and females $\left(r^{2}=0.90 ; p=0.021\right)$. Thus, corporal condition was analysed separately for each sex.

Both males and females of Trichomycterus sp. presented significant differences $(\mathrm{p}<0.05)$ in their corporal condition during the considered periods (Tables 5 and 6 ), and in the rainy season, fish were in better condition.

\section{Discussion}

Headwater streams are mostly inhabited by species of small fishes (Castro and Menezes, 1998). Castro (1999) affirms that small size is the pattern found in stream fish- 
es, and species smaller than $15 \mathrm{~cm}$ of length constitute, at least, $50 \%$ of stream species. Trichomycterus sp. is a type of small fish presenting, as suggested by Lemes and Garutti (2002), an adaptation to the small dimensions of headwater currents.

In accordance with Nikolski (1969), these fish species are able to manage continuous dynamic conditions, and their length structure can be modified according to the typical limits of the species, representing an adjustment faced with environmental changes, since survival conditions are regarded. The males of Trichomycterus sp.

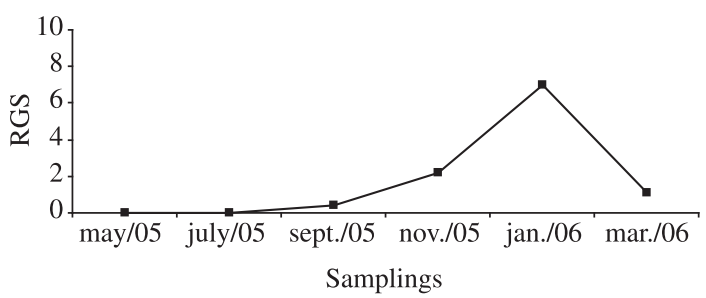

Figure 6. Gonadossomatoc relationship (RGS) for mature females of Trichomycterus sp. in each sampling. in Passa Cinco stream reach a larger size than females. Casatti (2003) also found similar results in length structure for males and females of the other Trichomycterus in a tributary of the Paranapanema river.

The analysis of population structure, related to fish sex, supplies important information for the knowledge of the relationship between individuals and the environment (Nikolski, 1969). In agreement with Nikolski (1963), the proportion between sexes varies considerably from species to species, and it could also vary inside the same population from one year to the next.

Braga (2006) draws attention to common mistakes that may occur in these kinds of studies, such as the ignorance of real segregation in those populations (presupposing 1:1) and sampling problems.

Trichomycterus sp. presented a proportion between males and females different from that expected, in a proportion of about two males for each female. Manriquez et al. (1988) for T.areolatus and Trajano (1997) for T. itacarambiensis also found differences in the proportion among the sexes, with approximately 1.5 males for each female.
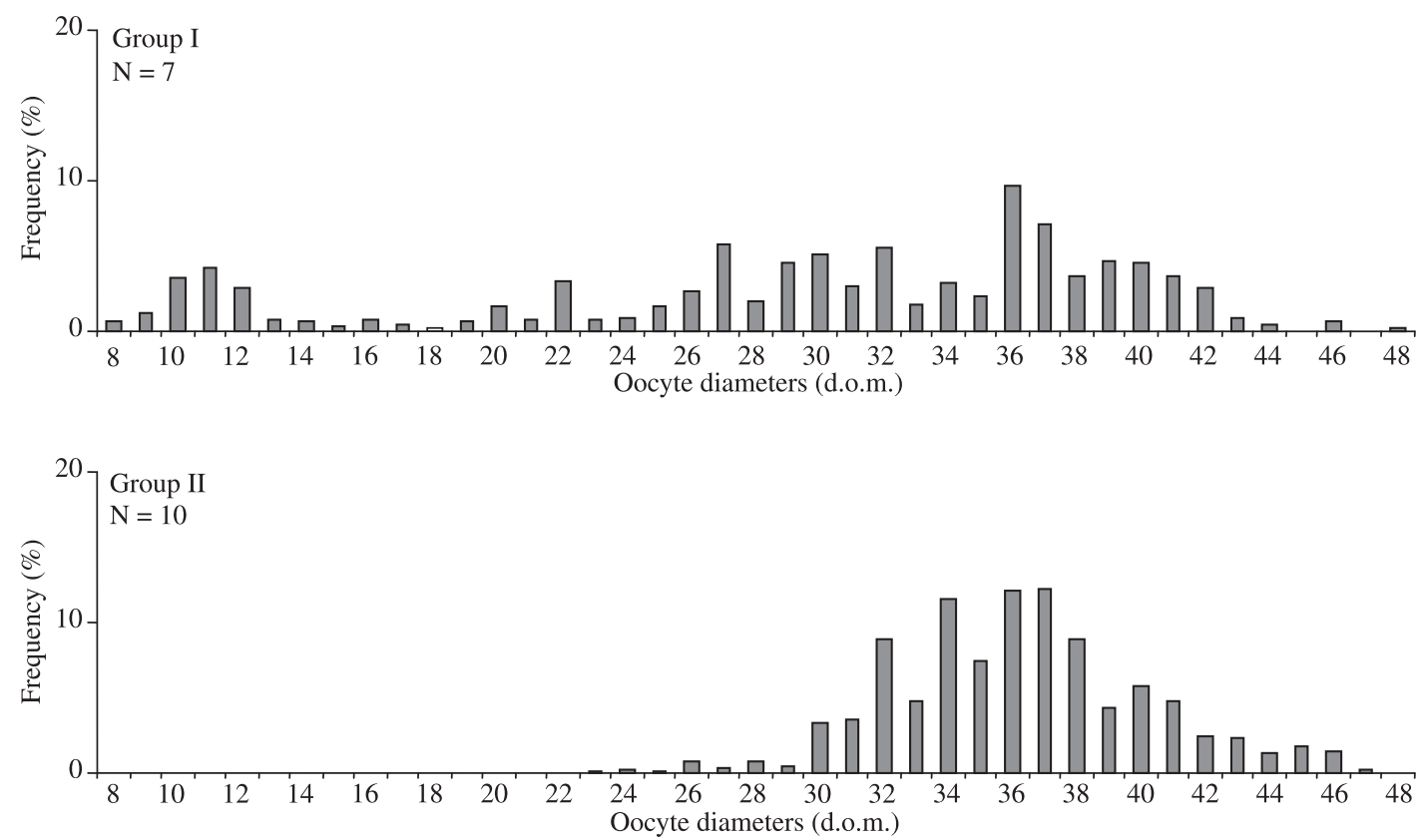

Figure 7. Distribution of oocyte diameter of Trichomycterus sp. according to each group of oocyte development (1 d.o.m. $=61.2 \mu \mathrm{m})$.

Table 4. Estimated values of a (intercept), b (angular coefficient) and $r$ (correlation coefficient) in length-weight relationship of males and females in drought and rainy season periods, considering $\mathrm{N}$ the number of specimens analysed.

\begin{tabular}{cllllr}
\hline Sex & Period & a & b & r & N \\
\hline Males & drought & 0.0001 & 2.4167 & 0.92 & 122 \\
& rainy season & 0.00006 & 2.6297 & 0.95 & 81 \\
\multirow{2}{*}{ Females } & drought & 0.00002 & 2.8559 & 0.79 & 61 \\
& rainy season & 0.0001 & 2.4594 & 0.76 & 38 \\
\hline
\end{tabular}


Table 5. Results of variance analysis of male weight of Trichomycterus sp according to sampling period and standard length $(\mathrm{SV}=$ source of variation; $\mathrm{SS}=$ sum of squares; $\mathrm{DL}=$ degrees of freedom; $\mathrm{SM}=$ square medium; $\mathrm{F}=$ test $\mathrm{F}$ ).

\begin{tabular}{crrrrc}
\hline SV & SS & DL & SM & F & P \\
\hline Period & 0.293 & 1 & 0.293 & 18.083 & $<0.0001$ \\
Length & 44.791 & 1 & 44.791 & 2768.507 & $<0.0001$ \\
Error & 3.236 & 200 & 0.016 & - & - \\
\hline
\end{tabular}

Table 6. Results of variance analysis of female weight of Trichomycterus sp according to sampling period and standard length $(\mathrm{SV}=$ source of variation; $\mathrm{SS}=$ sum of squares; $\mathrm{DL}=$ degrees of freedom; $\mathrm{SM}=$ square medium; $\mathrm{F}=$ test $\mathrm{F}$ ).

\begin{tabular}{lllrcc}
\hline \multicolumn{1}{c}{ SV } & \multicolumn{1}{c}{ SS } & \multicolumn{1}{c}{ DL } & SM & \multicolumn{1}{c}{ F } & \multicolumn{1}{c}{ P } \\
\hline Period & 0.256 & 1 & 0.256 & 13.937 & $<0.0001$ \\
Length & 5.844 & 1 & 5.844 & 318.131 & $<0.0001$ \\
Error & 1.763 & 96 & 0.018 & & \\
\hline
\end{tabular}

Munro (1976) explains that deviations observed in a proportion of 1:1 are, many times, a consequence of different growth rates observed in males and females, which may cause preferential capture on a large or small scale of specimens of one sex.

The diet of Trichomycterus sp. was composed mainly of aquatic insects, and immature Diptera was the most important item. Other previous studies confirm the information regarding the diet of Trichomycterus (Casatti, 2003; Habit et al., 2005; Chará et al., 2006 and Scott et al., 2007). Therefore, we can include Trichomycterus sp. in the guild of insectivore species. As emphasised by Esteves and Aranha (1999), the diversity of criteria usually applied to species classification in trophic guilds leads to a difficulty of comparison between feeding studies on fish. In general, the number of guilds defined depends on the taxonomic level correspondent to the classification of food items.

Lowe-McConnell (1999) affirms that in tropical environments, food chains are often based on few abundant food resources. Russo et al. (2002) and Henriques-Oliveira et al. (2003) draw attention to the family Chironomidae (Diptera), an abundant and widely distributed group that presents an important role in nutrient cycling. Ephemeroptera nymphs and immature Trichoptera, which are also important groups, survive only in quite oxygenated water and its high participation in diet of the species can be an indication of the good state of area conservation (Russo et al., 2002).

Aranha et al. (1998) and Esteves and Lobón-Cerviá (2001) relate punctual system alterations to the seasonal variation on the diet of studied species. Braga (2005) found differences in diets of two species in Ribeirão Grande system, Characidium lauroi, that inhabits montane piedmont streams, and $C$. alipioi, that inhabits the piedmont plain, according to the presence of different food items in those different environments. In Passa Cinco stream, the diet of Trichomycterus sp. didn't present variation in temporal and spatial dimensions, although a larger variety of food items has been consumed at site 1 . Thus, it is believed that the main food resources consumed by that species should be available during the whole year and through the stream course.

Vazzoler and Menezes (1992) declared that the reproductive period for the species in the Paraná river basin begins in October, when the temperature is elevated and the level of the waters begins to rise, reaching its peak in December-January, when the rainfall level is high. Trichomycterus sp., in Passa Cinco stream, followed that pattern, presenting reproductive period beginning at the end of the drought period, extending to the whole rainy season period.

In agreement with Nikolski (1963), parceled spawning and a long reproductive period are the main reproductive characteristics of tropical and subtropical fishes, and they consist of efficient adaptations for surviving in environments whose abiotic conditions are unfavorable.

The parceled spawning and the extensive reproductive period presented by Trichomycterus sp. showed to be in accordance with the information presented above, because this species inhabits the headwater area, that imposes variable and severe conditions on the organisms that live in this area (Allan, 1995).

Fecundity is a specific characteristic and it is adapted to the conditions of life cycle of species. It varies with growth, population density, food availability and mortality rate (Nikolski, 1969).

Trichomycterus sp. presented low fecundity and larger ovocytes. The reduction in the fecundity is compensated by larger oocytes, which give origin to larger immature individuals, with better capacity to explore the environment (Wooton, 1992). Braga et al. (2007) emphasize that small fishes in an environment of torrent streams can present low fecundity.

The low fecundity, large oocytes and parceled spawning presented by Trichomycterus sp. matches the information described above. Besides, it is believed that Trichomycterus sp. fits the opportunist strategy proposed by Winemiller (1989), taking into account that it is a small fish, that presents premature maturation, with average length in first gonadal maturation of $4.2 \mathrm{~cm}$ (Rondineli, 2007), and a long reproductive period synchronised with the rainy season.

In agreement with Mazzoni and Caramaschi (1997a, b), a high correlation between individual fecundity and individual total weight is expected. However, the correlation coefficients found for Trichomycterus 
sp. were very low. Marraro et al. (2005) also found low values of correlation for other Trichomycterus, T. corduvense. Mazzoni and Caramaschi (1997a) suggest a possible relationship of low correlation with the occurrence of parceled spawning.

The weight-length relationship is an important parameter for fish populations, and its applications vary from the estimative of individual weight, given that their length is known, to indications of corporal condition, besides being useful as an indicative of fat accumulation and development of gonads (Le Cren, 1951).

Alterations in corporal condition are associated to physiologic changes due to the reproductive cycle of the species, considering that feeding activity, fat development and fish reproduction are dependent on rainfall cycle (Bennemann et al., 1996). Those changes, which can occur to a greater or lesser degree, reflect the different reproductive strategies of the species.

Trichomycterus sp. presented better conditions in the rainy season, and the reproductive period also occurred at that time. A possible interpretation for a higher weight, considering a medium length for individuals of that species, would be the investment in reproduction. This species presents a reduced number of large oocytes rich in yolk, which in the final stages of maturation can occupy the whole visceral cavity, compressing the other organs and also contributing to an increment in weight.

Acknowledgements - The authors would like to thank FAPESP for the Master's scholarship conceded to the first author (proc. $n^{\circ}$ 04/12669-3), IBAMA (proc. $n^{\circ} 02027.000234 / 2005-05$ ) for authorising the license for the execution of the fieldwork, an anonymous reviewer for comments on the manuscript, and the designer Jaime R. Somera for map confection.

\section{References}

ALLAN, JD., 1995. Stream Ecology: structure and function of running water. New York: Chapman \& Hall.

ARANHA, JMR., TAKEUTI, DF. and YOSHIMURA, TM., 1998. Habitat use and food partitioning of the fishes in a coastal stream of Atlantic Forest, Brazil. Revista de Biologia Tropical, vol. 46, no. 4, p. $951-959$.

ARANHA, JMR., GOMES, JHC. and FOGAÇA, FNO., 2000. Feeding of two sympatric species of Characidium, C. lanei and C. pterostictum (Characidiinae) in a coastal stream of Atlantic Forest (Southern Brazil). Brazilian Archives of Biology and Technology, vol. 43 , no. 5 , p. 527-532.

ARRATIA, G., 1983. Preferencias de hábitat de peces siluriformes de aguas continentales de Chile (Família Diplomystidae y Trichomycteridae). Studies on Neotropical Fauna and Environment, vol. 18, p. 217-237.

BENNEMANN, ST., ORSI, ML. and SHIBATA, OA., 1996. Atividade alimentar de espécies de peixe do rio Tibagi, relacionada com o desenvolvimento de gordura e gônadas. Revista Brasileira de Zoologia, vol. 13, no. 2, p. 501-512.

BIZERRIL, CRSF., 1994. Descrição de uma nova espécie de Trichomycterus (Siluroidei, Trichomycteridae) do Estado de Santa Catarina, com uma sinopse da composição da família Trichomycteridae no leste Brasileiro. Arquivos de Biologia e Tecnologia, vol. 37, no. 3, p. 617-628.
BOCKMANN, FA. and SAZIMA, I., 2004. Trichomycterus maracaya, a new catfish from the upper rio Paraná, southeastern Brazil Siluriformes: Trichomycteridae, with notes on the T. brasiliensis species-complex. Neotropical Ichthyology, vol. 2, no. 2, p. 61-74.

BRAGA, FMS., 1990. Aspectos da reprodução e alimentação de peixes comuns em um trecho do rio Tocantins entre Imperatriz e Estreito, Estado do Maranhão e Tocantins, Brasil. Revista Brasileira de Biologia = Brasilian Journal of Biology, vol. 50, no. 3 , p. $547-558$.

1999. O grau de preferência alimentar: um método qualitativo e quantitativo para o estudo do conteúdo estomacal de peixes. Acta Scientiarum Biological Sciences, vol. 21, no. 2, p. 291-295.

2005. Feeding and condition factor of characidiin fish in Ribeirão Grande system, Southeastern Brazil. Acta Scientiarum Biological Sciences, vol. 27, no. 3, p. 271-276.

, 2006. Aspectos da reprodução no gênero Characidium Reinhardt, 1867 (Crenuchidae, Characidiinae), na microbacia do Ribeirão Grande, serra da Mantiqueira, sudeste do Brasil. Acta Scientiarum Biological Sciences, vol. 28, no. 4, p. 365-371.

BRAGA, FMS., SOUZA, UP. and CARMASSI, AL., 2007. Dinâmica populacional de Characidium lauroi $e \quad C$. alipioi (Teleostei, Crenuchidae) na microbacia do Ribeirão Grande, serra da Mantiqueira Oriental, estado de São Paulo. Acta Scientiarum Biological Sciences, vol. 29, no. 3, p. 281-287.

CASATTI, L., 2003. Biology of Cattfish, Trichomycterus sp. (Pisces, Siluriformes), in a Pristine Stream in the Morro do Diabo State Park, Southeastern Brazil. Studies on Neotropical Fauna and Environment, vol. 38, no. 2, p. 105-110.

CASTRO, RMC., 1999. Evolução da ictiofauna de riachos Sulamericanos: padrões gerais e possíveis processos causais. In: CARAMASCHI, EP., MAZZONI, R and PERES-NETO PR. (Eds). Ecologia de Peixes de Riachos, Série Oecologia Brasiliensis, vol. 6, p. $139-155$.

CASTRO, RMC. and MENEZES, NA., 1998. Estudo diagnóstico da diversidade de peixes do Estado de São Paulo. In: CASTRO, RMC (Ed.). Biodiversidade do Estado de São Paulo, Brasil: síntese do conhecimento ao final do século XX, W. São Paulo: FAPESP. vol. 6, p. 1-13.

CETRA, M., 2005. Avaliação do bem estar em peixes: ANCOVA uma alternativa para estudos da relação peso-comprimento. Boletim da Sociedade Brasileira de Ictiologia, no. 81, p. 3-5.

CHARÁ, JD., BAIRDS, DJ., TELFER, TC. and RUBIO, EA., 2006. Feeding ecology and habitat preferences of the catfish genus Trichomycterus in low-order streams of the colombian Andes. Journal Fish Biology, vol. 68, no. 4, p. 1026-1040.

COSTA, WJE., 1992. Description de huit nouvelles espèces du genre Trichomycterus (Siluriformes: Tricomicteridae), du Brésil oriental. Revue Française d'Aquariologie et Herpetologie, vol. 18, no. 4 , p. 101-110.

DE PINNA, MC., 1992. Trichomycterus castroi, a new species of trichomycterid catfish from the Rio Iguacu of Southestern Brazil (Teleostei: Siluriformes). Ichthyological Exploration of Freshwaters, vol. 3, no. 1, p. 89-95.

, 1998. Phylogenetic relationships of neotropical siluriforms (Teleostei: Ostariophysi): historical overview and synthesis of hypotheses. In: MALABARBA, LR., VARI, RE., LUCENA, ZM. and LUCENA, CA. (Eds.). Phylogeny and classification of neotropical fishes. Porto Alegre: Edipucrs. p. 279-330.

DE PINNA, MC. and WOSIACKI, WB., 2003. Family Trichomycteridae. In: REIS, RE., KULLANDER, SO. and 
FERRARIS, C.J. (Org). Check List of Freshwater Fishes of South and Central America. Porto Alegre: EDIPUCRS. p. 270-290.

ESTEVES, KE. and ARANHA, JMR., 1999. Ecologia trófica de peixes de riachos. In CARAMASCHI, EP., MAZZONI, R. and PERES-NETO, PR. (Eds). Ecologia de peixes de riacho, Série Oecologia Brasiliensis, vol. 6, p. 157-182.

ESTEVES, KE. and LOBÓN-CERVIÁ, J., 2001. Composition and trophic structure of a fish community of a clear water Atlantic rainforest stream in southeastern Brazil. Environmental Biology of Fishes, vol. 62, p. 429-440.

FERNÁNDEZ, L. and SCHAEFERR, S., 2003. Trichomycterus $y u s k a$, a new species from high elevations of Argentina (Siluriformes: Trichomycteridae). Ichthyological Exploration of Freshwaters, vol. 14 , no. 4 , p. $353-360$.

FERNÁNDEZ, L. and VARI, RP., 2000. New Species of Trichomycterus (Teleostei: Siluriformes: Trichomycteridae) Lacking a Pelvic Fin and Girdle from the Andes of Argentina. Copeia, no. 4, p. 990-996.

GARCIA, GJ., HEBERT, HD., PERINOTTO, JAJ. and CASTRO, JFM., 2004. (Eds). Atlas ambiental da Bacia do Rio Corumbataí. 2004. Available from:<http://www.rc.unesp.br>.

GOMIERO, LM. and BRAGA, FMS., 2005. Length structure of fishes from a protected área in the State of São Paulo, Southeastern Brazil. Acta Scientiarum Biological Sciences, vol. 27, no. 4, p. 339-346.

HABIT, E., VICTORIANO, P. and CAMPOS, H., 2005. Ecología trófica y aspectos reproductivos de Trichomycterus areolatus (Pisces, Trichomycteridae) en ambientes lóticos artificiales. Revista de Biologia Tropical, vol. 53, no. 1-2, p. 195-210.

HUAQUÍN, LG.,VELIZ, D. and ARRATIA, G., 2002. Estúdio comparativo de ovariosy cubiertas ovocitarias em peces siluriformes de águas continentales de Chile. Gayana, vol. 66, no. 2 , p. $269-274$

HENRIQUES-OLIVEIRA, AL., NESSIMIAN, JL. and DORVILLÉ, LFM., 2003. Feeding habitats of Chironomidae larvae (Insecta: Diptera) from a stream in the Floresta da Tijuca, Rio de Janeiro, Brazil. Revista Brasileira de Biologia $=$ Brazilian Journal of Biology, vol. 63, no. 2, p. 269-281.

LE CREN, ED., 1951. The lenght-weight relationship and seasonal cycle in gonad weight and condition in the perch (Perca fluviatilis). Journal of Animal Ecology, vol. 20, no. 2, p. 201-219.

LEMES, ME. and GARUTTI, V., 2002. Ecologia da ictiofauna de um córrego de cabeceira da bacia do Alto Paraná, Brasil. Iheringia, Série Zoologia, vol. 92, no. 3, p. 69-78.

LOWE-McCONNELL, RH., 1999. Estudos ecológicos em comunidades de peixes tropicais. São Paulo: Editora USP. 535 p.

MANRIQUEZ, A., HUAQUIN, L., ARELLANO, M. and ARRATIA, G., 1988. Aspectos reproductivos de Trichomycterus areolatus Valenciennes, 1846 (Pisces: Teleostei: Siluriformes) en Rio Angostura, Chile. Studies on Neotropical Fauna Environment, vol. 23, p. 89-102.

MARRARO, F., BISTONI, MA. and CARRANZA, M., 2005. Spawing season, ovarian development and fecundity of female Trichomycterus corduvense (Osteichthyes, Siluriformes). Hydrobiologia, vol. 534, p. 223-230.

MAZZONI, R. and CARAMASCHI, EP., 1997a. Spawing season, ovarian development and fecundity of Hypostomus affinis (Osteichthyes, Loricaridae). Revista Brasileira de Biologia = Brazilian Journal of Biology, vol. 57, no. 3, p. 455-462.

, 1997b. Observations on the reproductive biology of female Hypostomus luetkeni Lacepéde 1803. Ecology of Freshwater Fish, vol. 6, p. 53-56.
MUNRO, JJ., 1976. Aspects of the biology and ecology of Caribbean reef fishes: Mullidae (giat-fishes). Journal Fish Biology, vol. 9, p. 79-97.

NIKOLSKY, GV., 1963. The ecology of fishes. London: Academic Press. 325 p.

1969. Theory of fish population dynamics. Edinburgh: Oliver \& Boyd. 321 p.

POUILLY, M. and MIRANDA, G., 2003. Morphology and reproduction of the cavefish Trichomycterus chaberti and the related epigean Trichomycterus cf. barbouri. Journal Fish Biology, vol. 63 , no. 2, p. 490-505.

ROMÁN-VALENCIA, C., 2001. Ecología trófica y reproductiva de Trichomycterus caliense y Astroblepus cyclopus (Pisces: Siluriformes) en el río Quindio, Alto Cauca, Colômbia. Revista de Biologia Tropical, vol. 49, no. 2, p. 657-666.

RONDINELI, GR., 2007. Biologia alimentar e reprodutiva na comunidade de peixes do rio Passa Cinco (SP). Rio Claro, SP: Universidade Estadual Paulista. 147 p. [Dissertação de Mestrado].

RUSSO, MR., FERREIRA, A. and DIAS, RM., 2002. Disponibilidade de invertebrados aquáticos para peixes bentófagos de dois riachos da bacia do rio Iguaçu, Estado do Paraná, Brasil. Acta Scientiarum Biological Sciences, vol. 24, no. 2, p. 411-417.

SCOTT, S., PARDO, R. and VILA, I., 2007. Trophic niche overlap between two Chilean endemic species of Trichomycterus (Teleostei: Siluriformes). Revista Chilena de História Natural, vol. 80, no. 4, p. 341-437.

SIEGEL, S., 1975. Estatística não-paramétrica para as ciências do comportamento. Rio de Janeiro: McGraw-Hill do Brasil. 350 p.

SOKAL, RR. and ROHLF, FJ., 1995. Biometry. New York: WH Freeman and Company. 887 p.

TRAJANO, E., 1997. Food and reproduction of Trichomycterus itacarambiensis, cave catfish from southeastern. Journal Fish Biology, vol. 51, p. 53-63.

VALENTE, ROA., 2001. Análise da estrutura da paisagem na bacia do rio Corumbataí, SP. Piracicaba: Escola Superior de Agricultura "Luiz de Queiroz", Universidade de São Paulo. 162 p. [Dissertação de Mestrado]

VAZZOLER, AEAM., 1996. Biologia da reprodução de peixes teleósteos: teoria e prática. Maringá: EDUEM; São Paulo: SBI. $167 \mathrm{p}$.

VAZZOLER, AEAM. and MENEZES, NA., 1992. Síntese de conhecimento sobre comportamento reprodutivo de Characiformes da América do Sul (Teleostei, Ostariophysi). Revista Brasileira de Biologia = Brazilian Journal of Biology, vol. 52, no. 4, p. 627-640.

VIEIRA, S., 2004. Bioestatística: tópicos avançados. Rio de Janeiro: Elservier. 216 p.

WINEMILLER, KO., 1989. Patterns of variation in life history among South American fishes in seasonal environments. Oecologia, vol. 81 , p. $225-241$

WOOTON, RJ. 1992. Fish Ecology. New York: Chapman \& Hall. $212 \mathrm{p}$

WOSIACKI, WB., 2004. New species of the catfisf genus Trichomycterus (Siluriformes, Trichomycteridae) from the headwaters of the rio São Francisco Basin, Brazil. Zootaxa, vol. 592, p. 1-12.

, 2005. A new species of Trichomycterus (Siluriformes: Trichomycteridae) from south Brazil and redescription of $T$. ihering $i$ (Eigenmann). Zootaxa, vol. 1040, p. 49-64.

WOSIACKI, WB. and OYAKAWA, OT., 2005. Two new species of the catfish genus Trichomycterus (Siluriformes: Trichomycteridae) from the rio Ribeira de Iguape Basin, Southeastern Brazil. Neotropical Ichthyology, vol. 3, no. 4, p. 465-472. 